\title{
First Middle Ordovician conodont record related to key graptolites from the western Puna, Argentina: perspectives for an integrated biostratigraphy and correlation of the Central Andean Basin
}

\author{
Blanca A. Toro ${ }^{1}$, Susana E. Heredia², *Nexxys C. Herrera Sánchez ${ }^{1}$, Florencia Moreno² \\ I Universidad Nacional de Córdoba, Facultad de Ciencias Exactas, Físicas y Naturales, Consejo Nacional de Investigaciones Cientificas \\ y Tecnológicas (CONICET), Centro de Investigaciones en Ciencias de la Tierra, (CICTERRA), Av. Vélez Sarsfield 1611, X5016CGA, \\ Córdoba, Argentina. \\ btorogr@mendoza-conicet.gov.ar; nexxysherrera@gmail.com \\ ${ }^{2}$ Laboratorio de Micropaleontología, IIM (UNSJ)-CIGEOBIO, Consejo Nacional de Investigaciones Cientificas y Tecnológicas \\ (CONICET), Av. Libertador Gral. San Martín 1109, J5400, San Juan, Argentina. \\ sheredia@unsj.edu.ar; florenciamorenovaldez@gmail.com \\ * Corresponding author: nexxysherrera@gmail.com
}

\begin{abstract}
Recent biostratigraphic studies on the western argentine Puna recorded the Middle Ordovician conodont Baltoniodus cf. B. navis (Lindström) for first time, related to key graptolite taxa of the Central Andean Basin. The analyzed material comes from the lower and middle thirds of the turbidite succession exposed at the Huaytiquina section, Salta Province, which was previously assigned to the "Coquena" Formation. The conodont fauna was recovered from the calcareous sandstone beds intercalated in the middle portion of this unit, and it is composed by species of the genera Baltoniodus, Gothodus, Trapezognathus, Drepanoistodus, Drepanodus, and Protopanderodus, among others. The conodont association indicates a middle Dapingian (Dp2) age, linking the conodonts of the Argentine Puna with those from Baltoscandinavia and South China. The conodont productive levels also contain graptolites assignable to Tetragraptus bigsbyi (Hall) and Isograptus sp. They are located overlying strata bearing Azygograptus lapworthi Nicholson and underlying deposits with Xiphograptus lofuensis (Lee). The graptolite associations are indicating a Dapingian age (Dp1-Dp2) for the lower and middle portions of the "Coquena" Formation. The current findings from the western Puna, as well as the record of Azygograptus lapworthi related to the early Dapingian (Dp1) index conodont Baltoniodus triangularis in the Argentine Cordillera Oriental, are suggesting that a high-resolution correlation between both geomorphological regions is possible. This also documents that the Cordillera Oriental as well as the Puna were connected parts of the Central Andean Basin, during the interval from the Lower Ordovician (Floian) to the Middle Ordovician (Dapingian), instead of corresponding to the source and infill sectors of the basin, respectively. Furthermore, the regional and global correlations are discussed, and the potential of the Ordovician successions of the Argentine Puna for future advances on conodont-graptolite high-resolution biostratigraphy is highlighted.
\end{abstract}

Keywords: Conodonts, Graptolites, Puna, Argentina, Biostratigraphy, Correlation. 
RESUMEN. Primer registro de conodontes del Ordovícico Medio asociado a graptolitos clave de la Puna occidental, Argentina: perspectivas para una bioestratigrafía y correlación integrada de la Cuenca Andina Central. Nuevas investigaciones bioestratigráficas desarrolladas en el sector occidental de la Puna Argentina, permitieron obtener el primer registro del conodonte Baltoniodus cf. B. navis (Lindström) del Ordovícico Medio, asociado a especies características de graptolitos de la Cuenca Andina Central. El material analizado proviene de los tercios inferior y medio de la sucesión turbidítica expuesta en la sección de Huaytiquina, provincia de Salta, previamente asignada a la Formación "Coquena". La fauna de conodontes fue recuperada de los niveles de areniscas calcáreas intercalados en la parte media de la unidad, y se encuentra compuesta por especies de los géneros Baltoniodus, Gothodus, Trapezognathus, Drepanoistodus, Drepanodus y Protopanderodus, entre otros. La asociación de conodontes indica una edad dapingiana media (Dp2), relacionando los conodontes de la Puna Argentina con aquellos de Baltoescandinavia y del Sur de China. Los niveles productivos de conodontes también contienen graptolitos asignables a Tetragraptus bigsbyi (Hall) e Isograptus sp. Se encuentran ubicados por encima de los depósitos portadores de Azygograptus lapworthi Nicholson y por debajo de niveles con Xiphograptus lofuensis (Lee). Estas asociaciones de graptolitos indican una edad dapingiana (Dp1-Dp2) para los tramos inferior y medio de la Formación "Coquena". Tanto los presentes hallazgos en la Puna occidental, como el reciente registro de $A$. lapworthi, relacionado a niveles portadores del conodonte guía del Dapingiano temprano (Dp1) Baltoniodus triangularis en la Cordillera Oriental Argentina, sugieren que una correlación de alta resolución es posible entre ambas regiones morfoestructurales, a la vez que documentan que ambos sectores de la Cuenca Andina Central configuraban una cuenca marina durante el intervalo correspondiente al Ordovícico Inferior (Floiano)-Ordovícico Medio (Dapingiano), en lugar de corresponder respectivamente a las áreas de depositación y aporte de la misma. Por último, se discute la correlación regional y global de la sucesión estudiada, y se destaca el potencial de las sucesiones ordovícicas de la Puna Argentina para futuros avances bioestratigráficos de alta resolución de conodontes y graptolitos.

Palabras clave: Conodontes, Graptolitos, Puna, Argentina, Bioestratigrafia, Correlación.

\section{Introduction}

Conodonts and graptolites are the most important groups to define global stages and correlations of the Lower Palaeozoic sequences (Cooper et al., 2001; Bergström et al., 2004, 2009; Wang et al., 2005 , between others). They are widely distributed in the thick Ordovician successions of the Central Andean Basin, mainly in the Cordillera Oriental of northwestern Argentina, where their knowledge was significantly improved during the last decades (Toro and Brussa, 2003; Toro et al., 2015; Voldman et al., 2016, between others). On the contrary, graptolite records from the Puna highland continue scarcely studied and its knowledge includes taxonomic uncertainties, biostratigraphic gaps and confusing correlations; while only one conodont record, assigned to the Late Cambrian-Early Ordovician, was established for the Las Vicuñas Formation at the western Puna (Rao et al., 2000) prior to the newly report of Toro et al. (2019) at Huaytiquina section.

Toro $(1994,1997)$ and Toro et al. (2015) proposed a comprehensive biostratigraphic graptolite scheme comprising the Tetragraptus phyllograptoides, T. akzharensis, Baltograptus cf. B. deflexus and Didymograptellus bifidus biozones for the Floian deposits of the Acoite Formation exposed in the Cordillera Oriental of northwestern Argentina.
Later on, Albanesi and Ortega (2016) summarized a graptolite biostratigraphic framework for the Ordovician System of Argentina, including previously postulated graptolite biozones by diverse authors for the Argentine northwestern Andes. They referred the Azygograptus eivionicus Biozone (sensu Brussa et al., 2008) to the Lower Dp1?, based on the records of the nominal taxa in the Huaytiquina area, western Puna (Monteros et al., 1996), and the Muñayoc section, at the Quichagua range, northeastern Puna (Martínez et al., 1999). More recently, Toro (2017) recorded the first azygograptids from the Los Colorados and La Quiaca areas, at the western flank of the Argentine Cordillera Oriental, documenting the early Dapingian (Middle Ordovician) age of the bearer deposits. Toro and Lo Valvo (2017) suggested a Dapingian age for deposits carrying Isograptus cf. I. victoriae (Dp2) from the Tafna area, close to the border between Argentina and Bolivia; and Toro et al. (2018) described the first record of Xiphograptus lofuensis from the western flank of the Cordillera Oriental of Argentina, suggesting a probably Dapingian (Dp2) age for the bearer levels and their regional correlation with deposits of Chala Mayu, southern Bolivia, in which the Isograptus victoriae Biozone was described by Egenhoff et al. (2004). The last mentioned authors, proposed a graptolite biozonation based on the records from numerous stratigraphic sections located 
at the provinces of Tarija, Potosí and Chuquisaca, in southern Bolivia. They described the Rhabdinopora flabelliformis, Adelograptus sp., Aorograptus victoriae, Araneograptus murrayi, Hunnegraptus copiosus, Tetragraptus phyllograptoides, Expansograptus protobalticus, E. holmi, Baltograptus minutus, Azygograptus lapworthi and Isograptus victoriae local biozones and provided an international correlation with the Lower-Middle Ordovician graptolite biozones of Scandinavia and Eastern North America.

Ordovician conodonts from northwestern Argentina have been studied since decades (Rao, 1994, 1999; Rao and Hünicken, 1995; Albanesi and Ortega, 2016; Carlorosi and Heredia, 2017; Carlorosi et al., 2018, with complete references mentioned in the three last papers). These investigations produced important results on conodont biostratigraphy from the Ordovician northwestern sedimentary deposits that have been recorded into the geological provinces of Puna, Cordillera Oriental and Sierras Subandinas (Carlorosi and Heredia, 2017). The main region for conodont studies is currently represented by the Cordillera Oriental (Carlorosi and Heredia, 2017), but conodonts spanding the Cambrian-Ordovician boundary were reviewed recently by Giuliano et al. (2013) at Salar del Rincón area, western Puna. With regard to the Lower-Middle Ordovician conodont biostratigraphy of the Central Andean Basin, the contributions carried out by Carlorosi et al. (2013), Heredia et al. (2014); and Carlorosi et al. (2018) recorded several biozones: Trapezognathus diprion and Baltoniodus cf. B. triangularis as upper Floian zones, and B. triangularis (Carlorosi et al., 2013) and B. cooperi (Carlorosi et al., 2018) as lower Dapingian zone and subzone, respectively. The Dapingian conodont assemblages include the species: Baltoniodus triangularis Lindström, Baltoniodus pretriangularis (Lindström), Gothodus costulatus Lindström, Drepanoistodus pitjanti Cooper, Erraticodon patu Cooper, Trapezognathus diprion Lindström, Trapezognathus quadrangulum Lindström, Drepanodus sp., Oistodus sp., and Triangulodus sp. (Carlorosi and Heredia, 2017).

The aim of this contribution is to describe the first conodont record from the Middle Ordovician deposits of the western Argentine Puna and stratigraphically related graptolites, discussing the biostratigraphic ranges of conodont and graptolite key species, to precise the age of the bearing strata and possible biostratigraphic correlations.

\section{Geological Framework}

The Argentine Puna morpho-structural province is part of the high Andean plateau with an average altitude above 3,500 $\mathrm{m}$ that embraces together with the Cordillera Oriental, Sierras Subandinas and Sierras de Santa Bárbara, from the west to the east, the Argentine northwestern (Fig. 1A). This region was developed in a continental margin at western Gondwana, during the Cambrian-Ordovician times, as part of the Central Andean Basin (Sempère, 1995) which also includes parts of Chile, Bolivia and Peru (Astini, 2003).

Lower Paleozoic at Argentine Puna is represented by sedimentary deposits and associated volcanic rocks. It is widely accepted that the region comprises two submeridional belts corresponding to the eastern and western Puna (Turner, 1970) (Fig. 1B), which were developed from a Cambrian rifting margin to a Floian back-arc basin until a Darriwilian turbidite sequence at a foreland basin system (Astini, 2003, 2008 and references therein). Additionally, Egenhoff (2007) postulated that the evolution of the Central Andean Basin from an extensional basin, opening in the Cambrian, to a compressional regime, in the late Early Ordovician, triggering the basin closure in the latest Ordovician, reflects the relative movements of the Arequipa-Antofalla terrane alongside Gondwana. Conversely, Zimmerman (2011) refused the hypothesis of the terrane accretion processes, proposing the evolution of an active continental arc with associated basins and magmatic record for the proto-Andean margin of western Gondwana. According to this author, the Argentine Puna represents a retroarc basin environment composed by three different complexes, based on distinctive facies: Puna Volcanic Complex, Turbidite Complex and Shelf Complex (sensu Zimmerman, 2011). The author also proposed a correlation between the Puna shelf deposits and the shallow marine sedimentary successions in the Cordillera Oriental.

The studied Huaytiquina section is located at Salta Province, close to the border between Argentina and Chile, in the western belt of the Argentine Puna (Fig. 1B). Monteros et al. (1996) recognized two different stratigraphic units in the area, the Aguada de la Perdíz Formation, comprising the volcanosedimentary lower succession, and the "Coquena" Formation, which includes a $1,450 \mathrm{~m}$ thick turbidite dominated sedimentary deposits yielding graptolites. 


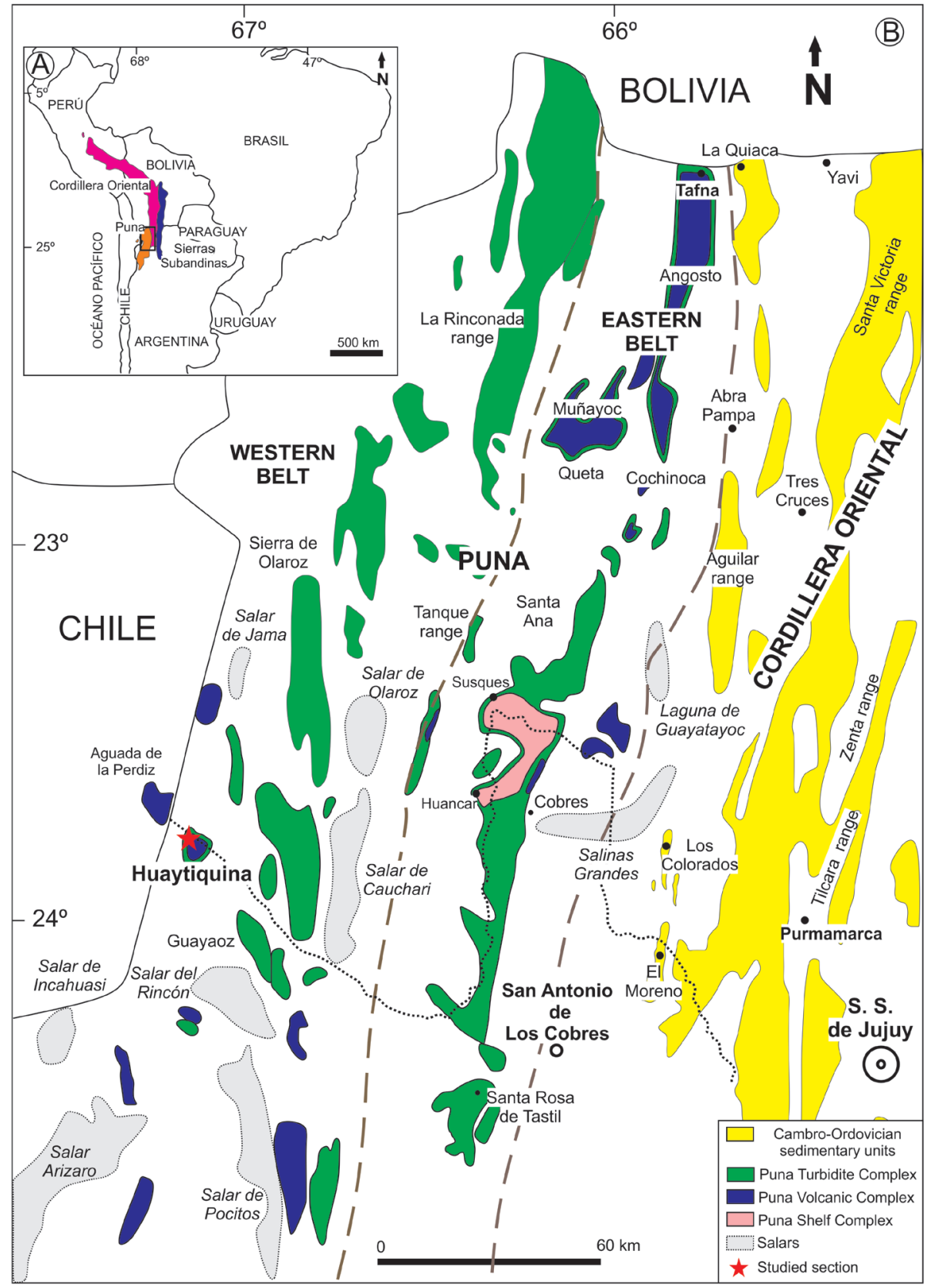

FIG. 1. Location map of northwestern Argentina showing the Ordovician deposits and fossiliferous localities at the Argentine Puna region and the Cordillera Oriental.

Afterwards, Zimmerman and Bahlburg (2003) and Zimmerman (2011) assigned a number of previously defined stratigraphic units from the western Argentine Puna, including the formations of the studied section, to the Puna Volcanic Complex and the Turbidite
Complex, respectively. According to these authors, these deposits are characterized by associations of mainly volcaniclastic rocks, andesites and rhyolites, tuffs and pyroclastic flows, turbidites, conglomerates and fine-grained sandstones, as well as immature 
coarse-grained wackes carrying graptolites and brachiopods; and large turbidite systems and channel systems, respectively. The fossil-bearing deposits correspond to the Puna Turbidite Complex sensu Astini (2003).

\section{Materials and Methods}

Two conodont bearing samples were collected from calcareous sandstone beds at random intervals on the "Coquena" Formation at the Huaytiquina section (Fig. 2). The samples were processed by formic acid technique described by Stone (1987). A total of 847 elements were obtained from HA sample $(1,03 \mathrm{~kg})$ and 277 from $\mathrm{H} 5$ sample $(0,67 \mathrm{~kg})$. The faunal diversity is relatively poor, but almost all identified species are biostratigraphically significant. Most of the recovered specimens exhibit excellent state of preservation, and different growth stages (juvenile, adult and mature) of each species recovered. The Color Alteration Index corresponds to a range of 1.5-2 of the Epstein et al. (1977) table. Conodont illustrations (Fig. 3) are SEM digital photomicrographs obtained by scanning electron microscope at the SEM Laboratory of IIM, Facultad de Ingeniería, Universidad Nacional de San Juan (Argentina). The conodont elements are deposited in collections of the INSUGEO- MP Collection of Microvertebrates Lillo-Conodonts under the code CML-C (Instituto Miguel Lillo and Universidad Nacional de Tucumán, Argentina).

With regard to the analyzed graptolites, we put emphasis in the detailed description and comparison of the material housed in the paleontological collection of the Centro de Investigaciones en Ciencias de la Tierra (CICTERRA), CONICET and Universidad Nacional de Córdoba, Argentina, under the prefix CEGH-UNC. This material is coming from the middle levels of the Huaytiquina section, at western Puna (Fig. 2) and was illustrated in the figure 4. The graptolite taxa collected from the Huaytiquina section by Monteros et al. (1996: pls. 1, 2) were stored as CNS-I 119/697:1-14 in the collection of the "Cátedra de Paleontología General de la Universidad Nacional de Salta, Argentina", but they are unfortunately missing. For this reason, their revision is based on the descriptions and illustrations provided by the authors, as well as on the geomorphometric analysis of the azygograptid species recently carried out by Herrera Sánchez et al. (2019).

\section{Systematic Paleontology}

\subsection{Conodonts}

Early Dapingian conodonts from northwestern Argentina were recently studied by Carlorosi et al. (2013, 2018) and Voldman et al. (2013) mostly referred to the $B$. triangularis Zone. Baltoniodus triangularis associated to B. cooperi Carlorosi, Sarmiento and Heredia (Carlorosi et al., 2018) was proposed by these authors representing the upper part of the $B$. triangularis Zone. Elements of $B$. cooperi were previously recognized by Albanesi and Vaccari (1994) and Albanesi and Ortega (2016), recovered from coquinoid beds from the upper part of the Suri Formation, but they were assigned to Baltoniodus navis sensu Cooper. In this sense, conodont elements with close affinity to $B$. navis were not recorded until now in the northwestern of Argentina (Fig. 5).

The great amount of the basin infilling that is characteristic of the northwestern Argentina offers the chance of recovering conodont specimens from the transition between species, Carlorosi et al. (2013, 2018) showed transitional forms of Baltoniodus and Trapezognathus from different intervals and locations in the Cordillera Oriental. Nevertheless, diversity of these studied conodont populations is low due to paleoenvironmental conditions controlled mostly by fine clastic input to the basin.

The species Baltoniodus navis, Gothodus cf. costulatus and Traprezognathus quadrangulum represent an assemblage already described for Baltoscandinavia (Bagnoli and Stouge, 1997, pag. 131).

\subsubsection{Previous comments on taxonomy: early Baltoniodus}

Lindström (1955) described for first time the species Prioniodus triangularis and P. navis, and stablished Prioniodus navis as the type species of the genus. Later, Lindström (1971) introduced the generic name Baltoniodus for these species. The revised diagnosis of $B$. navis was carried out by Lindström (1977), and he recognized prioniodiform (amorphognatiform and ambaloliform), ramiform and oistodiform elements describing especially the characters of the amorphognatiform element as having a quite distinct inner flare, posterior process longer than the other two and more than twice as long as the cusp 


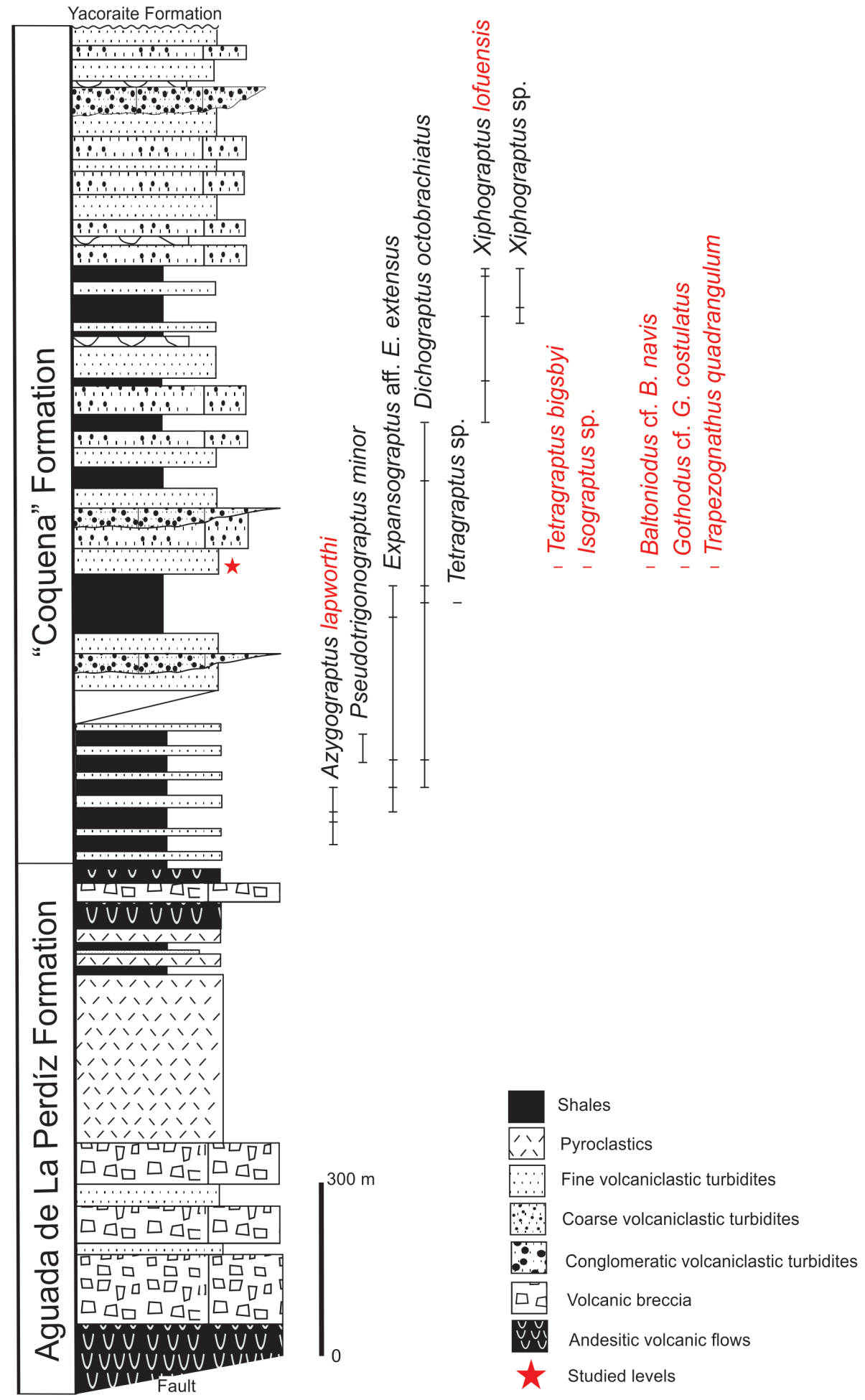

FIG. 2. Stratigraphic column of the Huaytiquina section at western flank of the Argentine Puna (modificated in red from Monteros et al., 1996: fig. 2), displaying the stratigraphic ranges of the significant graptolite and conodont taxa. 


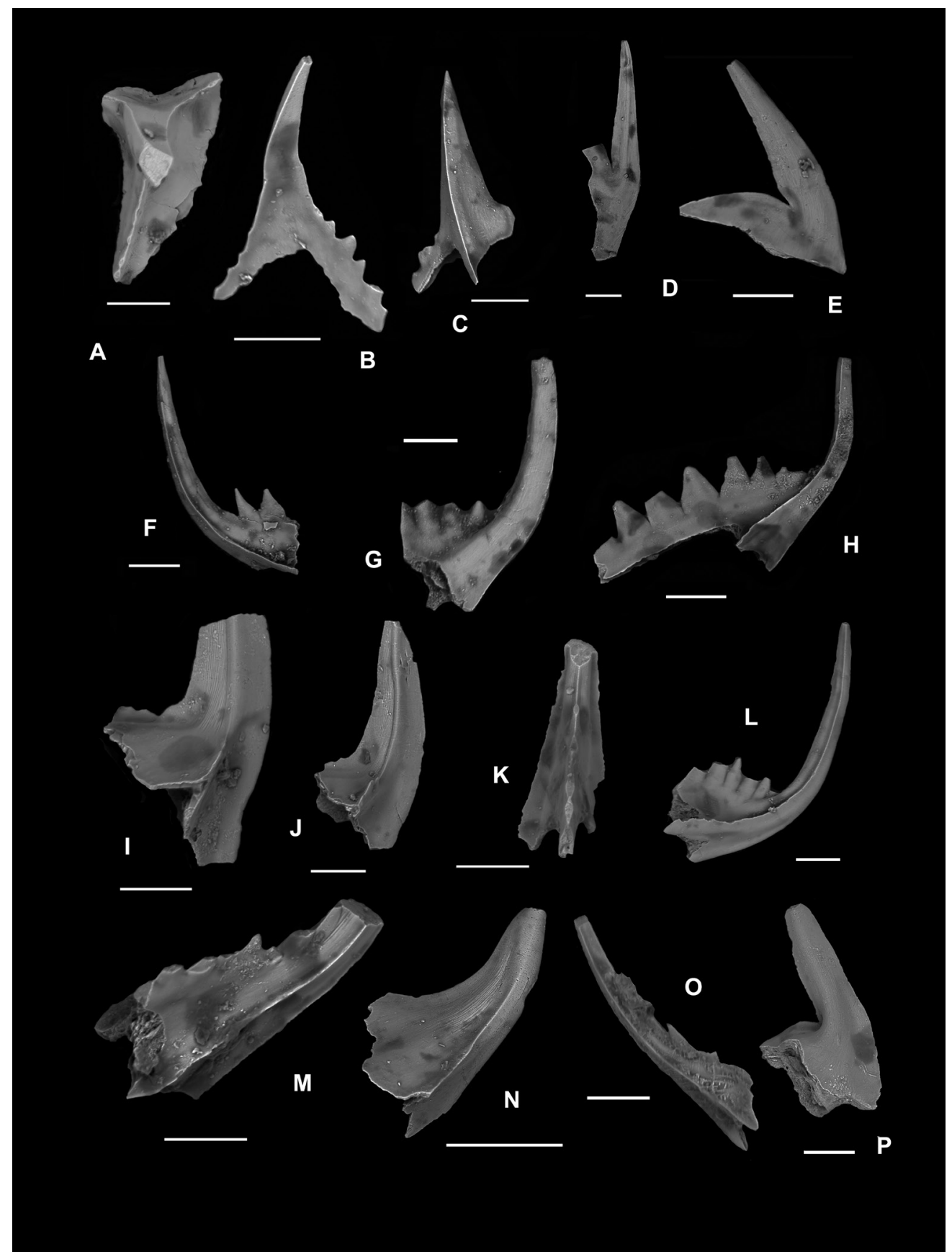

FIG. 3. Dapingian conodonts from the Huaytiquina section, Baltoniodus navis Zone. SEM Microphotographs. A-H. Baltoniodus cf. B. navis (Lindström). A, B. Pa element, upper view and anterior view respectively, sample H5, CML-C 3500(1), 3501(1). C. sinistral $\mathrm{Pb}$ element, anterior-lateral view, sample H5, CML-C 3502(1). D, E. M elements, lateral views , sample H5, CML-C 3507(1,2). F. Sa element, lateral view, sample H5, CML-C 3503(1). G. Sc element, lateral view, sample H5, 3505(1). H. Sd element, lateral view, sample H5,CML-C 3506(1). I-M. Gothodus cf. G. costulatus Lindström. I. Pa element, lateral view, sample HA, CML-C 3508(1). J. Pb element, lateral view, sample HA, CML-C 3509(1). K. Sa element, lateral view, sample HA, CML-C 3510(1). L. Sb element, lateral view, sample HA, CML-C 3511(1). M. Sd element, lateral view, sample HA, CML-C 3513(1). N-P. Trapezognathus quadrangulum Lindström. N. Pb element, lateral view, sample H5, CML-C 3515(1, 2). O. Sa element, lateral view, Sample H5, CML-C 3516(1, 2). P. M element, lateral view, sample H5, CML-C 3517(1). Scale bars: 0,1 mm. 

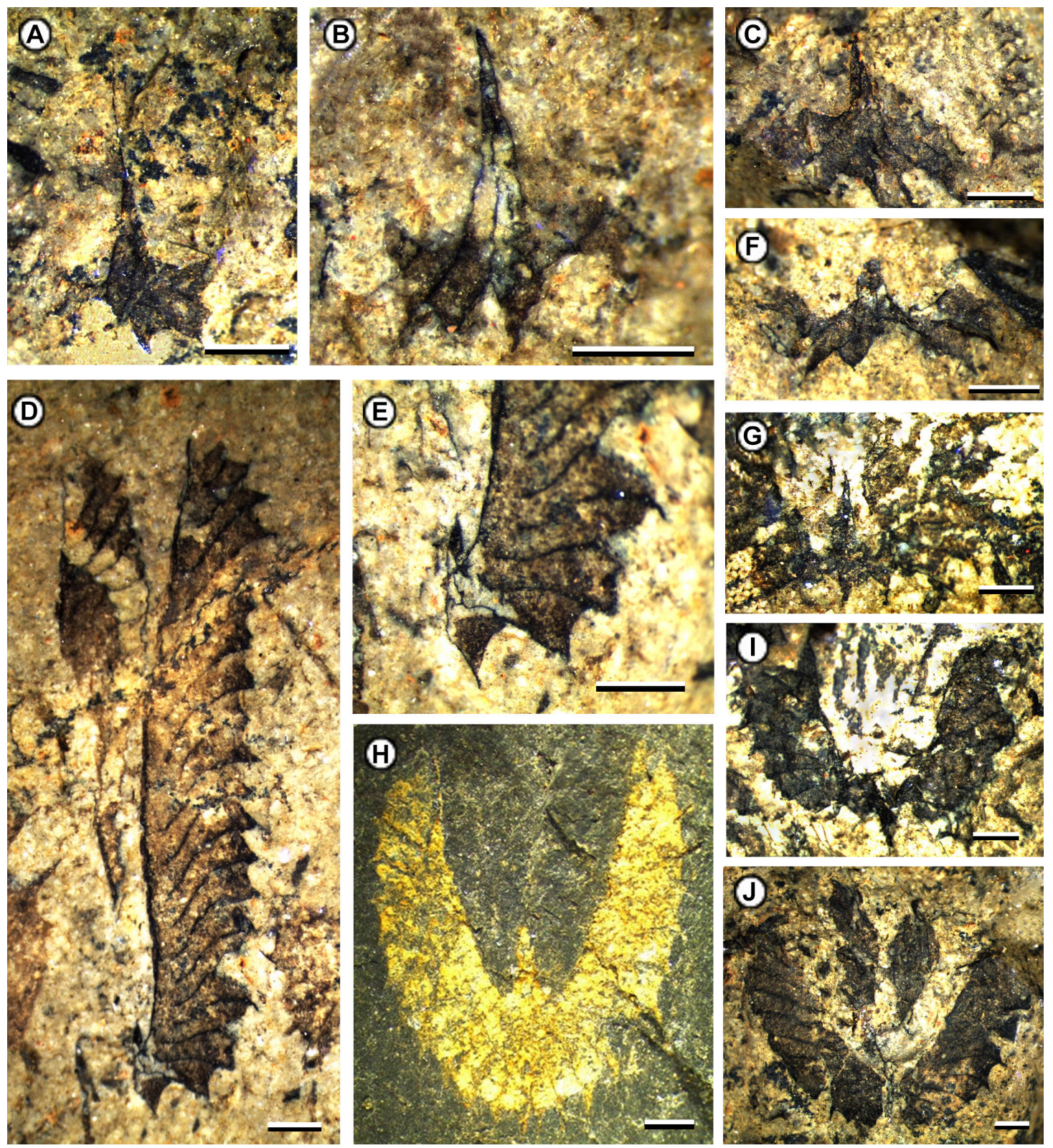

FIG. 4. Different early Dapingian (Dp2) graptolites taxa from the Argentine Puna. A, D-G, I-J. Tetragraptus bigsbyi (Hall) associated with Baltoniodus cf. B. navis at Huaytiquina section. A. Flattened proximal end showing conspicuous sicula with nema, CEGH-UNC 24969; D. Mature specimen with strongly reclined stipes and slightly sigmoid dorsal margins, CEGH-UNC 24972; E. Enlargement of the proximal portion of the specimen illustrated in D to highlight the sub-horizontal growing of the first theca, CEGH-UNC 24972; F. Juvenile specimen exhibiting sub-horizontal first thecae and reclined proximal end, CEGH-UNC 24968; G. Flattened juvenile specimen preserving long sicula and conspicuous apertural denticles, CEGHUNC 24971; I. Incomplete specimen showing the characteristic reclined stipes, CEGH-UNC 24970; J. Complete specimen showing the four strong reclined stipes, CEGH-UNC 24966. B, C. Isograptus sp. associated with Baltoniodus cf. B. navis at Huaytiquina section. B. Symmetric proximal end exhibiting a long sicula, CEGH-UNC 24973; C. Proximal end showing its symmetric appearance and the origin of the first theca from the long sicula, CEGH-UNC 24967. H. Isograptus cf. I. victoriae Harris from the Tafna area. Mature specimen showing the strongly reclined stipes and the symmetric appearance of the proximal end, CEGH-UNC 24974. Scale bars: $1 \mathrm{~mm}$. 


\begin{tabular}{|c|c|c|c|c|c|c|c|}
\hline \multicolumn{3}{|c|}{$\begin{array}{c}\text { GLOBAL } \\
\text { Bergström et al. } 2009\end{array}$} & \multicolumn{3}{|c|}{ GRAPTOLITES } & \multicolumn{2}{|c|}{ CONODONTS } \\
\hline \multirow{3}{*}{ 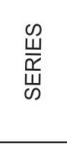 } & \multirow{3}{*}{ 岕 } & \multirow{3}{*}{ 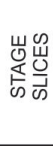 } & \multicolumn{3}{|c|}{ CENTRAL ANDEAN BASIN } & \multirow{2}{*}{\multicolumn{2}{|c|}{ CENTRAL ANDEAN BASIN }} \\
\hline & & & \multicolumn{2}{|c|}{ ARGENTINA } & \multirow{2}{*}{$\begin{array}{c}\text { BOLIVIA } \\
\text { Egenhoff et al. (2004) }\end{array}$} & & \\
\hline & & & $\begin{array}{c}\text { PUNA } \\
\text { Toro and Herrera Sánchez (2019) } \\
\text { This work }\end{array}$ & $\begin{array}{l}\text { CORDILLERA ORIENTAL } \\
\text { Toro et al. (2015) } \\
\text { Toro et al. (2018) }\end{array}$ & & Carlorosi a & $\begin{array}{l}\text { Heredia (2017) } \\
\text { work }\end{array}$ \\
\hline \multirow{2}{*}{ 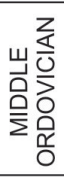 } & \multirow{2}{*}{$\begin{array}{l}z \\
\vdots \\
0 \\
z \\
0 \\
0 \\
\Delta\end{array}$} & กิ & "Isograptus victoriae" & $\begin{array}{c}? \\
\text { "Isograptus victoriae" }\end{array}$ & Isograptus victoriae & Baltor & us navis \\
\hline & & $\overline{\frac{2}{0}}$ & Azygograptus lapworthi & Azygograptus lapworthi & Azygograptus lapworthi & $\begin{array}{l}\text { Baltoniodus } \\
\text { triangularis }\end{array}$ & $\begin{array}{c}\text { B. cooperi } \\
\text { B. triangularis } \\
\text { early form }\end{array}$ \\
\hline \multirow{5}{*}{ 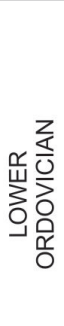 } & \multirow{5}{*}{ 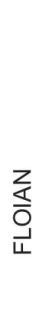 } & \multirow[b]{2}{*}{$\frac{m}{11}$} & \multirow{2}{*}{ Didymograptellus bifidus } & \multirow[b]{2}{*}{ Didymograptellus bifidus } & \multirow[b]{2}{*}{ Baltograptus minutus } & \multicolumn{2}{|c|}{ Baltoniodus cf. B. triangularis } \\
\hline & & & & & & \multicolumn{2}{|c|}{ Trapezognathus diprion } \\
\hline & & $\frac{N}{4}$ & Baltograptus cf. B. deflexus & Baltograptus cf. B. deflexus & Expansograptus holmi & & \\
\hline & & \multirow{2}{*}{$\overline{\frac{1}{4}}$} & & Tetragraptus akzharensis & Cymatograptus protobalticus & & \\
\hline & & & & Tetragraptus phyllograptoides & Tetragraptus phyllograptoides & & \\
\hline
\end{tabular}

FIG. 5. Biostratigraphic conodont-graptolite framework of the Lower-Middle Ordovician (F11 to Dp2) proposed for the Central Andean Basin. The shaped biostratigraphic range of B. cf. B. navis corresponds to the lowermost part of the eponymous conodont biozone.

is tall. Löfgren (1978) recognized six morphotypes of the apparatus such as amorphognatiform, ambalodiform, belodontiform (gothodiform and paracordylodondiform), tetraprioniodontiform, trichonodelliform and oistodontiform and also defined the surface microstructure like the fine longitudinal striae that characterize all elements of this genus (Löfgren, 1978). Cooper (1981) compared elements of Baltoniodus retrieved from the Horn Valley Siltstone, Amadeus Basin (Australia) to Baltoniodus navis (Lindström) from Baltoscandinavia; however the illustrated elements resulted not coincident with the Baltoniodus navis redescribed by Stouge and Bagnoli (1990). These authors recognized a septimembrate apparatus with $\mathrm{Pa}, \mathrm{Pb}, \mathrm{Sa}, \mathrm{Sb}, \mathrm{Sc}, \mathrm{Sd}$ and M elements. The origin and main characters of the early species of the genus Baltoniodus was carried out by Bagnoli and Stouge (1997) and Stouge and Bagnoli (1999).

Albanesi (1998) described and illustrated one Pa element from the Precordillera (Argentina) that he assigned to $B$. navis, mentioning that this element shows morphological intermediate characters with $B$. triangularis; a review of the illustrated element (pl. 2, fig. 13) shows closer characters to $B$. triangularis than B. navis.

Stouge and Bagnoli (1990) proposed that the earliest specimens of Baltoniodus derived from
Prioniodus Pander, but Carlorosi et al. (2013) illustrated early specimens of Baltoniodus $\mathrm{cf}$. B. triangularis sharing morphological characters with Trapezognathus diprion Lindström.

Following Lindström (1977) and Bagnoli and Stouge (1997) we find difficult to support that B. navis directly evolved from $B$. triangularis after there is not a precise record of this transition and there are many morphological differences between these species.

Middle and late forms of B. navis are well known from numerous studies throughout Middle Ordovician sections in Baltoscandinavia and South China (Löfgren, 1978; Stouge and Bagnoli, 1990, 1999; Bagnoli and Stouge, 1997; An, 1987). Only a probable early form was proposed by Bagnoli and Stouge (1997) from Sweden.

In the descriptions, we have used the conventional orientation terms -anterior, posterior and lateral- noting that these do not relate to the anatomical orientation of elements (see Purnell et al., 2000).
Class Conodonta Pander, 1856 Order Prioniodontida Dzik, 1976
Superfamily Prioniodontacea Bassler, 1925
Family Balognathidae Hass, 1959
Genus Baltoniodus Lindström, 1971 Type species: Prioniodus navis Lindström, 1955 
Remarks: The genus Baltoniodus has a septimembrate apparatus with pectniform, pastinate, alate, tertiopedate, bipennate, quadriramate and geniculate elements that are occupying $\mathrm{Pa}, \mathrm{Pb}, \mathrm{Sa}, \mathrm{Sb}, \mathrm{Sc}, \mathrm{Sd}$ and $\mathrm{M}$ positions.

\section{Baltoniodus cf. B. navis (Lindström, 1955) \\ Figure 3. A-H $M$ element}

1997 B. navis (Lindström), Bagnoli and Stouge, pl. 1, fig. 8.

1997 B. cf. navis (Lindström), Bagnoli and Stouge, pl. 1, fig. 9.

Description. The Pa element is a pastinate element. This element is characterized by their lateral compressed form with sharply flanks on the cusp. The cusp is long, twisted and delicate. The cusp has a triangular shape in a cross section view, from the flanks three denticulate processes develop: anterior, lateral and posterior. The anterior face of the cusp is sharp and ends in a short anterior process with denticles. The denticles on the anterior and lateral processes are regular and wide with triangular shape, but those on the anterior process are smaller and separated. The denticulate posterior process develops a small lobe whose location pointed out right and left forms. The denticles on the posterior process are erect with triangular shape and larger than the denticles of others processes. The basal cavity is elongated, open and deep. The basal sheath linking processes is wide and wavy (Fig. 3A, B).

Pb element: pastinate with tree processes. The cusp is similar to those of the Pa elements but more robust and shorter. It has triangular shape in a cross section view with sharp sides from which two processes are developed, the shortest lateral and the longest posterior. From the middle part of the cusp, a marked rib extends along the anterior process which is adenticulated. The lateral and posterior processes carry small triangular denticles, the first denticle of the lateral and posterior processes arise about the half of the cusp. The basal cavity is deep and extends to the processes; the basal sheath connects the processes but is less developed than that from the Pa element (Fig. 3C).

M element: is geniculate, laterally compressed with sharp edges. Two $\mathrm{M}$ elements were recognized, being the oistodiform one characterized by incipient denticles on the anterior side (Fig. 3D, E). The cusp is reclined to suberect. The anterior margin of the cusp appears as having a short or long extension directed downward. The posterior extension is also long.

Sa element: alate element. It has a long and thin proclined cusp with tree strong rib that extend beyond the cusp and form tree processes, two lateral and one posterior, only the posterior process carries triangular denticles with similar size and height. The basal cavity is deep and extends into the processes (Fig. 3F).

Sb element: Is a tertiopedate element. The cusp is slightly proclined; a strong rib on the inner side of the cusp gives rise to a posterior process. Two adenticulated lateral processes are recognized, they present a different angle which grants an asymmetry to the element. Denticles on the posterior process are long with triangular shape. The basal cavity is deep and runs into the processes.

Sc element bipennate: the cusp is long, with the external flank curved. The anterior process extends beyond the basal cavity and is directed to posterior side, this process ended in a keel; the inner flank is flat and extends in a posterior process that carries triangular and long denticles. The basal sheath is connecting the two processes and presents an undulation near the anterior one. The basal cavity is deep (Fig. 3G).

Sd element quadrirramate: it has a long proclined cusp, four processes are developed and their position are two latero-anterior and two lateroposterior. The posterior process carries denticles; these are long and triangular as those exhibited by the others $\mathrm{S}$ elements. The basal cavity is deep; the basal sheath is wide and connects the four processes given a quadrangular shape to the base (Fig. $3 \mathrm{H}$ ). Remarks: Baltoniodus cf. B. navis is represented in our collection by many specimens, all of them have a microstructure pattern on the element surface like fine longitudinal striae. Compared with $B$. navis the denticulation is larger but only the posterior process of the $\mathrm{S}$ elements has denticles. The $\mathrm{Pa}$ and $\mathrm{Pb}$ elements resemble to Baltoniodus cooperi (in Carlorosi et al., 2018), mainly the $\mathrm{Pb}$ element. The $\mathrm{M}$ elements are very similar to those of $B$. navis and $B$. cf. navis (illustrated by Bagnoli and Stouge, 1997). The specimens at hand are interpreted as early representatives of the species Baltoniodus navis.

Material: 443 elements in the HA sample: 3524(1212), 3525(1-162), 3526(1-69); 124 elements H5 sample: 3500(1), 3501(1), 3502(1), 3503(1), 3504(1), 
3505(1), 3506(1), 3507(1, 2), 3527(1-55), 3528(136), 3529(1-24).

Provenance: H5 sample, lower B. navis Zone. "Coquena" Formation, Huaytiquina section, Salta Province, Argentina.

Genus Trapezognathus Lindström, 1955

Type species: Trapezognathus quadrangulum Lindström, 1955

Trapezognathus quadrangulum Lindström, 1955 Figure 3. N-P

1955 Prioniodus triangularis Lindström, pp. 591, 592 (partim), pl. 5, fig. 45 (only).

1955 Prioniodus navis Lindström, pp. 590, 591 (partim), pl. 5, figs. 31, 32 (only).

1955 Trapezognathus quadrangulum Lindström, p. 598 (partim), pl. 5, figs. 38, 39 (only).

1977 Baltoniodus triangularis (Lindström), Lindström, pp. 81-82 (partim), Baltoniodus, pl. 2, figs. ?8, ?9.

1978 Prioniodus (Baltoniodus) triangularis Lindström; Löfgren, pp. 81, 82, pl. 12, fig. 1.

1990 Trapezognathus quadrangulum Lindström; Stouge and Bagnoli, pp. 26, 27, pl. 10, figs. 1-5. 1997 Trapezognathus quadrangulum Lindström;

Bagnoli and Stouge, p. 160, pl. 8, figs. 1-5.

2003 Icriodella n. sp. A., Moya et al., p.64, pl. 12 figs. 13, 15.

Remarks: $\mathrm{Pb}, \mathrm{S}$ and $\mathrm{M}$ elements were recovered. This species was widely described by Carlorosi and Heredia (2017). These elements resemble to those from the Santa Gertrudis Formation (Carlorosi et al., 2018).

Material: 5 elements, $3515(1,2), 3516(1,2), 3517(1)$ Provenance: H5 sample, lower B. navis Zone. "Coquena" Formation, Huaytiquina section, Salta Province, Argentina.

Family Phragmodontidae Bergström, 1981

Genus Gothodus Lindström, 1955

Type species: Gothodus costulatus Lindström, 1955

Gothodus ef. G. costulatus Lindström, 1955

Figure 3I-M

$P$ element

1997 Gothodus costulatus Lindström, Bagnoli and Stouge, pp. 141, pl. 2, figs. 11-13. M element

1997 Gothodus costulatus Lindström, Bagnoli and Stouge, pp. 141, pl. 2, fig. 10.
Remarks: the Gothodus cf. G. costulatus specimens in our collection show many similarities to those described by Bagnoli and Stouge (1997) except that the $\mathrm{P}, \mathrm{M}$ and $\mathrm{S}$ elements develop fine striae on the cusp and few fine costae behind the keel of the cusp. Material: 318 elements in the HA sample: 3508(1), 3509(1), 3510(1), 3511(1), 3512(1), 3513(1), 3514(1), 3518(1-114), 3519(1-90), 3520(1-107). 116 elements in the H5 sample: 3521(1-58), 3522(1-36), 3523(1-22). Provenance: $\mathrm{H} 5$ and HA sample, lower $B$. navis Zone. "Coquena" Formation, Huaytiquina section, Salta Province, Argentina.

\subsection{Graptolites}

For the taxonomic classification of the studied graptolites at upper level than genus we follow the recent proposes of Maletz and Zhang (2016) and Maletz et al. (2018), and the revision of the species Tetragraptus bigsbyi provided by Williams and Stevens (1988). The last authors emphasised that Skevington (1965) divided the original species of T. bigsbyi in two separated taxa based only on the stipe attitude, and despite the fact of all the material coming from a single stratigraphical level. Consequently, they consider that continuous variations observed between T. bigsbyi and T. pseudobigsbyi suggesting that both species are synonymous.

\section{Phyllum Hemichordata Bateson 1885, (emend. Fowler, 1892)}

Order Graptoloidea Lapworth, 1875 in Hopkinson and Lapworth, 1875

Suborder Dichograptina Lapworth, 1873

Family Phyllograptidae Lapworth, 1873

Genus Tetragraptus Salter, 1863

Type species: Tetragraptus serra

(Brongniart, 1828)

Diagnosis: (Maletz et al., 2018) Phyllograptid with four horizontal to reclined, reflexed and scandent stipes; proximal end isograptid, dextral, with wide crossing canals and tetragraptid proximal end; theca with considerable overlap and moderate development of rutellum.

Tetragraptus bigsbyi (Hall, 1865)

Figure 4A; 4D-G; 4I-J

1858 Phyllograptus similis Hall, p. 40. 
1865 Graptolithus bigsbyi Hall, pp. 86-88; pl. 16, figs. 22-30.

1902 Tetragraptus bigsbyi, Elles and Wood, pp. 68-69; pl. 6, figs. 6d-e; figs. 42a-b.

1988 Tetragraptus bigsbyi; Williams and Stevens, p. 31; pl. 2, figs. 7-8; text-figs. 19C-O, non 19A?, B?. And synonymies therein.

Material. Numerous specimens corresponding to different stages of development regularly preserved as flattened films and internal molds. The illustrated material is identified as CEGH-UNC 24966, 24968, 24969, 24970, 24971, 24972.

Description. Robust tubaria with four reclined stipes that reach a maximum of $14 \mathrm{~mm}$ in length (Fig. 4D). In juvenile specimens that preserve the sicula, it commonly varies between 1.5 to $1.7 \mathrm{~mm}$ long and 0.4-0.6 mm of apertural diameter (Fig. 4A, E, G). Th $1^{1}$ originates at the upper part of the sicula, and the two first thecae grow sub-horizontal conferring the asymmetric proximal end of the tubarium (Fig. 4F, G). The thecae are strong curved to the distal part, developing apertural denticles, which are usually obscured by the rock matrix (Fig. 4G, J). Dorsalventral width of the stipes increases from $1.5 \mathrm{~mm}$ up to $2.5 \mathrm{~mm}$ and the thecal density is 13-14 thecae in 10 $\mathrm{mm}$. Dorsal margin of the stipes in mature specimens display a slightly sigmoid curvature (Fig. 4D).

Discussion. The studied material present the general characteristics previously described by Skevington (1965) and later discussed by Williams and Stevens (1988) in T. bigsbyi. The measurements of the proximal end, such as the sicular length, the apertural width of the sicula, and the distance of growing of the first theca from the sicular apex, are also agreeing with those described in T. bigsbyi.

The specimens here assigned to T. bigsbyi are associated at the same stratigraphic level with fragments of stronger stipes that reach $60 \mathrm{~mm}$ in length and $4 \mathrm{~mm}$ of width, that probably correspond to the second order stipes of the T. serra. It is also important to mention another younger specimens that show symmetrical proximal ends, similar to those characteristics of isograptids (Fig. 4B, C).

Geographic and stratigraphic provenance. The studied material was collected for the first time in the Argentine Puna, from the middle portion of the "Coquena" Formation, Salta Province (Fig. 2). Levels containing T. bigsbyi are located approximately 300 meters above to the last record of Azygograptus lapworthi, recently assigned to the Dapingian (Dp1) of the Central Andean Basin (Toro, 2017; Toro and Herrera Sánchez, 2019), and they correspond to the overlaying "Isograptus victoriae" Biozone (Dapingian, Dp2, sensu Toro and Herrera Sánchez, 2019, fig. 2.A).

Toro and Brussa (2003) summarized the records of $T$. bigsbyi from the Argentine Precordillera, corresponding to the Isograptus victoriae maximus, Oncograptus upsilon, Cardiograptus morsus, Undulograptus austrodentatus and Undulograptus dentatus biozones.

Williams and Stevens (1988) observed that T. bigsbyi is a very widespread form described from a variety of stratigraphical horizons, and they assigned the type material from Point Levis, Canada, to the T. akzharensis-I. victoriae lunatus biozones. The species had also been recorded from Scandinavia (Bulman, 1936; Skevington, 1965).

\section{Suborder Glossograptina Jaanuson, 1960 \\ Family Isograptidae Harris, 1933 \\ Genus Isograptus Moberg, 1892}

Type species: Didymograptus gibberulus Nicholson, 1875

Diagnosis: (Maletz and Zhang, 2016) Reclined twostiped isograptids; dextral, thecae simple with rutellate apertures, shorter and wider in earlier species, with thecal length increasing in later species; proximal development type isograptid, dextral, with low prosicular origin of th $1^{1}$, rarely sinistral.

\section{Isograptus sp. Figure 4B, $C$}

Material. Two specimens corresponding to early stages of development. The material is identified as CEGH-UNC 24967, 24973.

Description. Juvenile specimens exhibiting long sicula with rutellum, which vary between 2.3 to $2.5 \mathrm{~mm}$ in length and $0.7 \mathrm{~mm}$ of apertural width (Fig. 4B, C). Th $1^{1}$ originates at the upper part of the sicula, at approximately $0.3 \mathrm{~mm}$ from the apex and grows downwards. It develops a symmetric proximal end with the sicula, conferring to the tubarium the distinctive isograptid symmetry characteristic of the genus Isograptus.

Discussion. The material assigned to Isograptus $\mathrm{sp}$. differs considerably from the associated proximal 
ends corresponding to Tetragraptus bigsbyi, mainly in the bigger dimensions of the proximal end, such as the sicular length and apertural width of the sicula. Forms included in the genus Isograptus exhibit remarkable pendent direction of growing of the first thecae from the upper part of the sicula, in contrast to the subhorizontal growing of the first thecae in T. bigsbyi (Fig. 4E, F).

The occurrence of Isograptus sp. in the Huaytiquina section and the xiphograptids previously mention by Monteros et al. (1996) in the studied area, are confirming that both taxa are associated in levels of Dapingian (Dp2) age in the Central Andean Basin. Geographic and stratigraphic provenance. Specimens assigned to the genus Isograptus were previously collected from equivalent levels cropping out at Tafna area (Toro and Lo Valvo, 2017) and Chala Mayu section, southern Bolivia (Egenhoff et al., 2004). Isograptus sp. is located for the first time at the Huaytiquina section, approximately 300 meters above to the last record of Azygograptus lapworthi (Fig. 2). The association of this taxon with the key conodont Baltoniodus cf. B. navis is confirming the conodont-graptolite biostratigraphic framework proposed for the Central Andean Basin (Fig. 5).

\section{Biostratigraphyc Framework and Correlations}

\subsection{Conodonts}

The $B$. navis Zone is an interval biozone defined by the first appearance of this species to the first appearance of Microzarkodina parva. In the reference section of north of Horns Udde (Sweden) this biozone is represented by a measured rock sequence of $1.68 \mathrm{~m}$ (Bagnoli and Stouge, 1997). The Hagudden section (Sweden) records part of this biozone probably the $P$. (B.) triangularis-navis Zone of Löfgren (1978) after measured rock sequence of $c a$. $0.20-0.25 \mathrm{~m}$ thick (Stouge and Bagnoli, 1990). Even though we have not an extensive collection of conodonts through the entire Huaytiquina section, we consider the present record of the $B$. cf. B. navis as a marker of the lower part of the eponymous zone. A more detailed biostratigraphic research to accurate the thickness and boundaries of this biozone are under development. The conodont biostratigraphy are currently in agreement with the graptolite framework proposed for the Central Andean Basin (Toro et al.,
2015, 2018) (Fig. 5). The lower Dapingian conodont record in northwestern Argentina is well represented by the Baltoniodus triangularis Zone (Carlorosi et al., 2013). Carlorosi et al. (2018) recently proposed that the Pa elements of $B$. triangularis from the Alto del Cóndor Formation could be interpreted as early forms of this species, and that would represent the lowermost part of the biozone. On the other hand, late forms of this species associated to B. cooperi from the Santa Gertrudis Formation were proposed as index conodonts for the uppermost part of this biozone (Carlorosi et al., 2018). The morphological similarities between the $\mathrm{Pb}$ elements of $B$. cooperi and $B$. cf. $B$. navis suggest a strong evolutionary link that deserves more studies.

\subsection{Graptolites}

For biostratigraphic discussions we follow the graptolite biostratigraphic framework recently proposed by Toro et al. $(2015,2018)$ and Toro and Herrera Sánchez (2019), based on the first record of the index species or the characteristic taxa associations previously recognized at different levels of a certain biozone in different stratigraphic sections of the northwestern Argentina and southern Bolivia. As the Early-Middle Ordovician graptolite taxa in the Central Andean Basin clearly indicate cold to temperate faunal affinities; we referred the ages and correlations to the global stage slices proposed by Bergström et al. (2009) to solve previous misunderstandings related to the use of the Australian standard stages, which have been established on key species with warm faunal affinities. Additionally, an updated graptolite-conodont biostratigraphic framework for the Lower Ordovician (Floian) to Middle Ordovician (Dapingian) in the Central Andean Basin is presented in figure 5 , as a complete reference for the discussion of regional correlations.

Based on the first records for Argentina of Azygograptus eivionicus, D. (Expansograptus) sp. aff. D. (E.) extensus, Dichograptus octobrachiatus, Pseudotrigonograptus minor and Tetragraptus sp. in the lower third of the "Coquena" Formation at the Huaytiquina section; and Xiphograptus svalbardensis (X. lofuensis, sensu Toro and Brussa, 2003) and Xiphograptus sp. in the middle part of this unit, Monteros et al. (1996) assigned to the yielding levels and age corresponding to the Ca1-Ya1 interval of the Australian sequence. 
Herrera Sánchez et al. (2019) recently reviewed all the records of azygograptids from the northwest of Argentina and southern Bolivia concluding that all of them correspond to Azygograptus lapworthi, and Toro y Herrera Sánchez (2019) proposed the eponymous biostratigraphical interval for the Middle Ordovician (early Dapingian Dp1) in the Central Andean Basin. Accordingly, we assume that the Azygograptus lapworthi Biozone is developing through the lower part of the "Coquena" Formation at Huaytiquina section up to the studied levels (Fig. 2) (Toro and Herrera Sánchez, 2019, fig. 2A). The revision of Azygograptus lapworthi interval from the western flank of the Quichagua range at the northeastern Puna (Herrera Sánchez et al., 2019; Toro and Herrera Sánchez, 2019) allows postulating a regional correlation with the studied levels in which the mentioned species is present at Huaytiquina section.

First findings of Azygograptus lapworthi at Los Colorados and La Quiaca areas (Toro, 2017; Toro and Herrera Sánchez, 2019) allowed extend the distribution of this biostratigraphical interval to the western flank of the Cordillera Oriental, where the related conodont records, corresponding to the early Dapingian (Dp1), confirm the regional correlation of the bearing levels with the lower part of the "Coquena" Formation at Huaytiquina section.

A regional correlation is also possible with the Azygograptus lapworthi Biozone, first analyzed in the Central Andean Basin at southern Bolivia in the Sama-Chaupi Uno and Sella areas. Maletz and Egenhoff (2003) and Egenhoff et al. (2004) described in more detail the Azygograptus lapworthi Biozone, defining its base at the first occurrence of the eponymous species and proposing an international correlation with the Pseudophyllograptus angustifolius elongatus Biozone of Scandinavia and the Isograptus victoriae lunatus of Eastern North America.

It is noteworthy, the similar distribution between the key conodont species Baltoniodus triangularis associated with azygograptids that occurs in the Huanghuachang GSSP section, across the boundary interval for the formal base of the Dapingian Stage in Yichang, southern China (Cooper and Sadler, 2012; fig. 20.4 and references therein), and those mentioned from the Central Andean Basin.

Toro and Lo Valvo (2017) postulated a younger (Dp2) age for strata of the "Coquena" Formation that carry isograptids of the "I. victoriae group" (Fig. 4.h) coming from the Tafna area, at western flank of the Argentine Puna. On the other hand, Toro et al. (2018) described Xiphograptus lofuensis for the first time in the Cordillera Oriental in the upper part of the Los Colorados section, suggesting an equivalent age for the bearer deposits. Newly records of Isograptus sp. here described in association with Baltoniodus cf. $B$. navis, are documenting the "Isograptus victoriae" Biozone through the middle part of the "Coquena" Formation at Huaytiquina section, and the Dapingian (Dp2) age of the studied deposits (Toro and Herrera Sánchez, 2019, fig. 2A). Accordingly, the correlation with the previous mentioned levels is here confirmed. The interval of the "Isograptus victoriae" Biozone from the Huaytiquina section is also regionally correlated with the Isograptus victoriae Biozone of southern Bolivia (Fig. 5), first mentioned in the Chala Mayu section by Müller (2000) and successively described by Egenhoff et al. (2004) and Toro and Maletz (2018), who furthermore of the eponymous species mentioned Xiphograptus cf. X. lofuensis, Pseudophyllograptus sp. and Tetragraptus sp.

\section{Conclusions}

New records of Baltoniodus cf. B. navis associated with Tetragraptus bigsbyi and Isograptus sp., located in the middle portion of the "Coquena" Formation, at the Huaytiquina section confirm a Middle Ordovician (Dapingian, Dp2) age for the studied levels.

The Azygograptus lapworthi Biozone (early Dapingian, Dp1, sensu Toro and Herrera Sánchez, 2019) is developing below of the studied levels, whereas the overlaying deposits with Xiphograptus lofuensis corresponds to the "Isograptus victoriae" (Dapingian, Dp2, sensu Toro and Herrera Sánchez, 2019).

The biostratigraphic distribution of the studied conodont association is in agreement with the graptolite biozonation, previously proposed for the Lower-Middle Ordovician of the Central Andean Basin, and allows to precise the boundary between the last mentioned biostratigraphic units.

The biostratigraphic distribution of the index conodonts (Baltoniodus triangularis and B.cf. $B$. navis), as well as the ranges of the graptolite key taxa (Azygograptus lapworthi and Isograptus sp.) document a high resolution regional correlation between the Ordovician successions located at the Puna region, as Quichagua and Huaytiquina, and 
classical localities at the Cordillera Oriental of Argentina and Bolivia, as Los Colorados, La Quiaca and Chaupi Uno.

The calibration through conodont records of remarkably complete Lower Ordovician graptolite succession of the Cordillera Oriental (Tetragraptus phyllograptoides, T. akzharensis, Baltograptus $\mathrm{cf} . B$. deflexus and Didymograptellus bifidus), and younger units of the Puna region and Cordillera Oriental of Bolivia (Azygograptus lapworthi and Isograptus victoriae), provides new insights for global correlation and solid perspectives to fill remaining gaps and solve uncertainties.

\section{Acknowledgements}

This work was supported by ANPCYT, PICT 2016-0558. It is a contribution to 653 IUGS-IGCP international project -The onset of the Great Ordovician Biodiversification Event-. Lic. Inés Castro is acknowledged for SEM images (IIM-Facultad de Ingeniería, Universidad Nacional de San Juan). The authors are grateful to Dr. J. Carlorosi, Dr. J.C. Gutiérrez-Marco and Dr. W. Vivallo Sandoval for the useful revisions that greatly improved this work.

\section{References}

Albanesi, G. 1998. Taxonomía de conodontes de las secuencias ordovícicas del Cerro Potrerillo, Precordillera Central de San Juan, República Argentina. Academia Nacional de Ciencias de Córdoba, Actas 12: 99-253.

Albanesi, G.; Ortega, G. 2016. Conodont and graptolite biostratigraphy of the Ordovician System of Argentina. In Stratigraphy \& Timescales (Montenari, M., editor). Elsevier: 61-121.

Albanesi, G.; Vaccari, E. 1994. Conodontos del Arenig en la Formación Suri, Sistema del Famatina, Argentina. Revista Española de Micropaleontología 26 (2): 125-146.

An, T.X. 1987. Early Paleozoic Conodonts from South China. Peking University Publishing House: 238 p. Beijing

Astini, R.A. 2003. The Ordovician Proto-Andean Basins. In Ordovician Fossils of Argentina (Benedetto, J.L., editor). Secretaria de Ciencia y Tecnología, Universidad Nacional de Córdoba: 1-74. Córdoba.

Astini, R.A. 2008. Sedimentación, facies, discordancias y evolución paleoambiental durante el CambroOrdovícico. In Congreso Geológico Argentino, No. 17, Geología y Recursos Naturales de La Provincia de Jujuy, Relatorio: 50-73. Jujuy.

Bagnoli, G.; Stouge, S. 1997. Lower Ordovician (Billingenian-Kunda) conodont zonation and provinces based on sections from Horns Udde, north Öland, Sweden. Bollettino della Società Paleontologica Italiana 35: 109-163.

Bassler, R.S. 1925. Classification and stratigraphic use of the conodonts. Geological Society of American Bulletin 36: 218-220.

Bateson, W. 1885. The later stages in the development of Balanoglossus kowalevskii, with a suggestion as to the affinities of the Enteropneusta. Quarterly Journal of Microscopical Science 25: 81-122.

Bergström, S.M. 1981. Conodonta. In Treatise on Invertebrate Paleontology, part W, Miscellanea, suppl. 2, W1-W202 (Robison, R.A., editor). Geological Society of America and University of Kansas, Boulder. Colorado and Lawrence, Kansas.

Bergström, S.M.; Löfgren, A.; Maletz, J. 2004. The GSSP of the second (upper) stage of the Lower Ordovician Series: Diabasbrottet at Hunneberg, Province of Vaastergötland, southwest Sweden. Episodes 27 (4): 265-272.

Bergström, S.M.; Chen, X.; Gutiérrez-Marco, J.C.; Dronov, A. 2009. The new chronostratigraphic classification of the Ordovician System and its relations to major regional series and stages and to $\delta^{13} \mathrm{C}$ chemostratigraphy. Lethaia 42: 97-107.

Brongniart, A. 1828. Histoire des végétaux fossiles, ou recherches botaniques et géologique sur les végétaux renformés dans les diverses couches du globe. Ed. d'Ocagne: 488 p. Paris.

Brussa, E.D.; Toro, B.A.; Vaccari, N.E. 2008. Bioestratigrafía del Paleozoico Inferior en el ámbito de la Puna. In Congreso Geológico Argentino, No. 17, Geología y Recursos Naturales de La Provincia de Jujuy. Relatorio: 93-97. Jujuy.

Bulman, O. M. B. 1936. On the graptolites prepared by Holm. Part 7. The graptolite fauna of the Lower Orthoceras Limestone of Hälludden, Öland, and its bearing on the evolution of the Lower Ordavieian graptolites . Arkiv för Zoologi 28A (17): 107 p.

Carlorosi, J.; Heredia, S. 2017. Bioestratigrafía de conodontes ordovícicos del Noroeste Argentino. In Congreso Geológico Argentino. Ciencias de la Tierra, No. 20, y Recursos Naturales del NOA, Relatorio: 671-686. Tucumán.

Carlorosi, J.; Heredia, S.; Aceñolaza, G. 2013. Middle Ordovician (early Dapingian) conodonts in the Central Andean Basin of NW Argentina. Alcheringa 37 (3): 299-311.

Carlorosi, J.; Heredia, S.; Sarmiento, G. 2018. Selected Middle Ordovician key conodont species from the Santa 
Gertrudis Formation (Salta, Argentina): an approach to its biostratigraphical significance. Geological Magazine 155 (4): 878-892.

Cooper, B.J. 1981. Early Ordovician conodonts from the Horn Valley Siltstone, Central Australia. Palaeontology 24: 147-183.

Cooper, R.A.; Sadler, P.M. 2012. The Ordovician Period. In The Geologic Time Scale 2012 (Gradstein, F.; Ogg, J.G.; Schmitz, M.D.; Ogg, G.M.; editors). Volume 2. Elsevier: 489-523.

Cooper, R.A.; Nowlan, G.S.; Williams, H.S. 2001. Global stratotype section and point for base of the Ordovician System. Episodes 24: 19-28.

Dzik, J. 1976. Remarks on the evolution of Ordovician conodonts. Acta Palaeontologica Polonica 21: 395-455.

Egenhoff, S.O. 2007. Life and death of a CambrianOrdovician basin: An Andean three-act play featuring Gondwana and the Arequipa-Antofalla terrane. In The evolution of the Rheic Ocean: From AvalonianCadomian active margin to Alleghenian-Variscan collision (Linnemann, U.; Nance, R.D.; Kraft, P.; Zulauf, G.; editors). Geological Society of America Special Paper 423: 511-524.

Egenhoff, S.O.; Maletz, J.; Erdtmann, B.D. 2004. Lower Ordovician graptolite biozonation and lithofacies of southern Bolivia: relevance for palaeogeographic interpretations. Geological Magazine 141: 287-299.

Elles, G.L.; Wood, E.M.R. 1902. A monograph of British graptolites. Paleontographical Society of London, Monograph 171: 55-102.

Epstein, A.G., Epstein, J.P.; Harris, L. 1977. Conodont alteration: an index to organic metamorphism. US Geological Survey, Professional Paper 995: 1-27.

Fowler, G.H. 1892. The morphology of Rhabdopleura allmani. In Festschrift zun $70^{\circ}$ Geburstag (Leuckarts, R.; editor), Ed. W. Engelmann: 293-297. Leipzig.

Giuliano, M.E.; Ortega, G.; Albanesi, G.; Monaldi, C.R. 2013. Upper Cambrian/Lower Ordovician conodont and graptolite records in the Lari section, Salar del Rincón, Puna of Salta, Argentina. In Conodonts from the Andes (Albanesi, G.; Ortega, G.; editors). Ameghiniana, Publicación Especial 13-Paleontological Note: 33-37.

Hall, J. 1858. Descriptions of Canadian graptolites. Geological Survey of Canada, Report of Progress for 1857: 111-145. Reprinted as: Notes upon the genus Graptolithus, and descriptions of some remarkable new forms from the shales of the Hudson River Group, discovered in the investigations of the Geological Survey of Canada. The Canadian Naturalist and Geologist, and Proceedings of the Natural History Society of Montreal 3: 139-150, 162-177.

Hall, J. 1865. Graptolites of the Quebec Group. Figures and Descriptions of Canadian Organic Remains: $151 \mathrm{p}$.

Harris, W.J. 1933. Isograptus caduceus and its allies in Victoria. Proceedings of the Royal Society of Victoria (new series) 46: 79-114.

Hass, W. H. 1959. Conodonts from the Chappel limestones of Texas. US Geological Survey Professional Paper 294: 365-400.

Heredia, S.; Carlorosi, J.; Sarmiento, G. 2014. Taxonomic review of the early species of the conodont genus Baltoniodus Lindström and its distribution in the Ordovician of Gondwana. In International Paleontological Congress, No. 4, Abstract: 349. Mendoza.

Herrera Sánchez, N.C.; Degrange, F.J.; Toro, B.A.; Lo Valvo, G. 2019. Geomorphometric analysis of Azygograptus species (Graptolithina) from the Central Andean Basin. Publicación Electrónica de la Asociación Paleontológica Argentina 19 (1): p. R54.

Hopkinson, J.; Lapworth, C. 1875. Descriptions of the graptolites of the Arenig and Llandeilo rocks of St. David's. Quarterly Journal of the Geological Society 31: 631-672.

Jaanusson, V. 1960. Graptoloids from the Ontikan and Viruan (Ordov.) Limestones of Estonia and Sweden. Bulletin of the Geological Institutions of the University of Uppsala 38 (3-4): 289-366.

Lapworth, C. 1873. On an improved classification of the Rhabdophora. Geological Magazine 10: 500-504, 555-560.

Lindström, M. 1955. Conodonts from the lowermost Ordovician strata of south-central Sweden. Geologiska Föreningens i Stockholm Förhandlingar 76: 517-604.

Lindström, M. 1971. Lower Ordovician conodonts of Europe. In Symposium on conodont biostratigraphy, (Sweet, W.C.; Bergström, S.M.; editors), Geological Society of America Memoirs 127: 21-61.

Lindström, M. 1977. Baltoniodus. In Catalogue of Conodonts I (Ziegler, W.; editor). E. Schweizerbart`sche Verlagsbuchhandlung: 1-504. Stuttgart.

Löfgren, A. 1978. Arenigian and Llanvirnian conodonts from Jämtland, Sweden. Fossils and Strata 13: 1-129.

Maletz, J.; Egenhoff, S.O. 2003. Lower to Middle Ordovician graptolite biostratigraphy of southern Bolivia. Revista Técnica de YPFB 21:103-115.

Maletz, J.; Zhang, Y. 2016. Part V, Second Revision, Suborder Glossograptina: Introduction, Morphology, 
and Systematic Descriptions. Treatise Online 79: $1-22$.

Maletz, J.; Toro, B.A.; Zhang, Y.; Vandenberg, A.H.M. 2018. Treatise on Invertebrate Paleontology,Part V, revised, Suborder Dichograptina Lapworth 1873: Introduction, Morphology, and Systematic Descriptions. Treatise Online 108: 1-28.

Martínez, M.; Brussa, E.D.; Pérez, B.; Coira, B. 1999. El Ordovícico de la sierra de Quichagua (Puna nororiental argentina): litofacies volcanosedimentarias y graptofaunas. In Congreso Geológico Argentino, No. 14, Actas I: 347-350. Salta.

Moberg, J.C. 1892. Om några nya graptoliter från Skånes Undre Graptolithskiffer. Geologiska Föreningens i Stockholm Förhandlingar 14 (4): 339-350.

Monteros, J.A.; Moya, M.C.; Monaldi, C.R. 1996. Graptofaunas arenigianas en el borde occidental de la Puna Argentina. Implicancias paleogeográficas. In Congreso Geológico de Bolivia, No. 12, Memorias: 733-746. Tarija.

Moya, M.C.; Malanca, S.; Monteros, J.A.; Albanesi, G.; Ortega, G.; Buatois, L.A. 2003. Late CambrianTremadocian faunas and events from the Angosto del Moreno Area, Eastern Cordillera, Jujuy Province. In Ordovician from the Andes (Albanesi, G.; Beresi, M.S.; Peralta, S.H.; editors). In International Symposium on the Ordovician System, No. 9, Serie de Correlación Geológica 17: 439-444. San Juan.

Müller, J. 2000. Tektonische Entwicklung und Krustenverkürzung der Ostkordillere Südboliviens $\left(20.7^{\circ} \mathrm{S}-21.5^{\circ} \mathrm{S}\right)$ (Tectonic evolution and crustal shortening of the Eastern Cordillera of southern Bolivia). Ph.D. Thesis (Unpublished), Freie Universität Berlin: 197 p.

Nicholson, H.A. 1875. On a new genus and some new species of graptolites from the Skiddaw Slates. Annals and Magazine of Natural History 16: 269-272.

Pander, C.H. 1856. Monographie der fossilen Fische des silurischen Systems der Russisch-Baltischen Gouvernements. St Petersburg: Kaiserliche Akademie der Wissenschaften: $91 \mathrm{p}$.

Purnell, M.A.; Donoghue, P.C.J.; Aldridge, R.J. 2000. Orientation and anatomical notation in conodonts. Journal of Paleontology 74: 113-122.

Rao, R.I. 1994. Conodontes ordovícicos de la Sierra de Cajas y del Espinazo del Diablo Departamento Humahuaca, Provincia de Jujuy, República Argentina. Ph.D. Thesis (Unpublished), Universidad Nacional de Córdoba, Facultad de Ciencias Exactas, Físicas y Naturales: 332 p.
Rao, R.I. 1999. Los conodontes cambro-ordovícicos de la Sierra de Cajas y del Espinazo del Diablo, Cordillera Oriental, República Argentina. Revista Española de Micropaleontología 31 (1): 23-51.

Rao, R.I. ; Hünicken, M. 1995. Conodontes del Cámbrico Superior-Ordovícico Inferior en el área de Purmamarca, Cordillera Oriental, Provincia de Jujuy, Argentina. Boletín de la Academia Nacional de Ciencias 60 (3-4): 249-266. Córdoba.

Rao, R., Moya, M.C.; Hünicken, M. 2000. Conodontes de la Formación Las Vicuñas (Tremadoc temprano), Puna Occidental Argentina. Ameghiniana Suplemento Resúmenes 37 (4): R13-14.

Salter, J.W. 1863. Note on the Skiddaw Slate fossils. Quarterly Journal of the Geological Society of London 19: 135-140.

Sempère, T. 1995. Phanerozoic evolution of Bolivia and adjacent regions. In Petroleoum basins of South America (Tankard, A.J.; Suárez Soruco, R.; Welsink, H.J.; editors). AAPG Memoir 62: 207-230.

Skevington, D. 1965. Graptolites from the Ontikan Limestones (Ordovician) of Öland, Sweden. II. Graptoloidea and Graptovermida. Bulletin of the Geological institutions of the University of Uppsala 43: 1-74.

Stone, J. 1987. Review of investigative techniques used in the study of conodonts. In Conodonts: Investigative Techniques and Applications (Austin, R.; editor), Chichester: Ellis Horwood Limited: 17-34.

Stouge, S.; Bagnoli, G. 1990. Lower Ordovician (VolkhovianKunda) conodonts from Hagudden, northern Öland, Sweden. Palaeontographia Italica 77: 1-54.

Stouge, S.; Bagnoli, G. 1999. The suprageneric classification of some Ordovician prioniodontid conodonts. Bollettino della Società Paleontologica Italiana 37 (2-3): 145-158.

Toro, B.A. 1994. Taxonomía, bioestratigrafía y afinidades paleobiogeográficas en base a las graptofaunas ordovícicas del borde occidental de la Cordillera Oriental, provincia de Jujuy, Argentina. Ph.D. Thesis (Unpublished), Universidad Nacional de Córdoba, Facultad de Ciencias Exactas, Físicas y Naturales: 173 p. Córdoba

Toro, B.A. 1997. La fauna de graptolitos de la Formación Acoite, en el borde occidental de la Cordillera Oriental Argentina. Análisis bioestratigráfico. Ameghiniana 34 (4): 393-412.

Toro, B.A. 2017. Primeros registros del género Azygograptus Nicholson y Lapworth, en Nicholson, 1875 (Graptolithina) en la Cordillera Oriental de 
Argentina. Ameghiniana Suplemento Resúmenes 54 (4): 50.

Toro, B.A; Brussa, E.D. 2003. Graptolites. In Ordovician fossils of Argentina (Benedetto, J.L., editor), Secretaría de Ciencia y Tecnología, Universidad Nacional de Córdoba: 441-505. Córdoba.

Toro, B.A.; Herrera Sánchez, N.C. 2019. Stratigraphical distribution of the Ordovician graptolite Azygograptus Nicholson \& Lapworth in the Central Andean Basin (NW Argentina and S Bolivia). Comptes Rendus Palevol 18 (5): 493-507.

Toro, B.A.; Lo Valvo, G. 2017. Implicancias bioestratigráficas y correlación de nuevos registros de graptolitos del Ordovícico Inferior y Medio en la transecta ToqueroYavi, Provincia de Jujuy, Argentina. Ameghiniana Suplemento Resúmenes 54 (4): 51.

Toro, B.A.; Maletz, J. 2018. Up-to-date overview of the Ordovician and Silurian graptolites from Bolivia. In Fósiles y Facies de Bolivia (Suárez Riglos, M.; Dalenz Farjat, A.; Perez Leyton, M.A.; editors): 59-81. Santa Cruz de la Sierra.

Toro, B.A.; Meroi Arcerito, F.R.; Muñoz, D.F.; Waisfeld, B.G.; de la Puente, G.S. 2015. Graptolite-trilobite biostratigraphy in the Santa Victoria area, northwestern Argentina. A key for regional and worldwide correlation of the Lower Ordovician (Tremadocian-Floian). Ameghiniana 52 (5): 535-557.

Toro, B.A.; Herrera Sánchez, N.C.; Navarro, J.M.; Muñoz, D.F. 2018. Fisrt record of the Xiphograptus genus (Graptolithina) in the Cordillera Oriental, Argentina. Publicación Electrónica de la Asociación Paleontológica Argentina 18 (2): 54.

Toro, B.A.; Heredia, S.; Herrera Sánchez, N.C.; Moreno, F.; Lo Valvo, G. 2019. First conodonts record in the Argentine Puna related to Middle Ordovician graptolites. Publicación Electrónica de la Asociación Paleontológica Argentina 19 (1): R82-R83.

Turner, J.C.M. 1970. The Andes of Northwestern Argentina. Geologische Rundschau 59: 1028-1063.

Voldman, G.; Albanesi, G.; Ortega, G.; Giuliano, M.E.; Monaldi, C.R. 2016. New conodont taxa and biozones from the Lower Ordovician of the Cordillera Oriental Argentina, NW Argentina. Geological Journal 52 (3): 394-414. doi: 10.1002/gj.2766.

Voldman, G.; Albanesi, G.; Zeballo, F.; Monaldi, C. 2013. Early Ordovician (Late Floian) conodonts from the Zenta Range, Cordillera Oriental, NW Argentina. In Conodonts from the Andes (Albanesi, G.; Ortega, G.; editors). Publicación Especial, No. 13, Paleontological Note: 123-128.

Wang, X.; Stouge, S.; Erdtmann, B.-D.; Chen, X.; Li, Z.; Wang, C.; Zeng, Q.; Zhou, Z.; Chen, H. 2005. A proposed GSSP for the base of the Middle Ordovician Series: The Huanghuachang section, Yichang, China. Episodes 28 (2): 105-117.

Williams, S.H.; Stevens, R.K. 1988. Early Ordovician (Arenig) graptolites of the Cow Head Group, western Newfoundland, Canada. Palaeontographica Canadiana 5: $167 \mathrm{p}$.

Zimmermann, U. 2011. From fore-arc to foreland: a cross section of the Ordovician in the Central Andes. In Ordovician of the World (Gutiérrez-Marco, J.C.; Rábano I.; García-Bellido D.; editors). Cuadernos del Museo Geominero 14: 667-674.

Zimmermann, U.; Bahlburg, H. 2003. Provenance analysis and tectonic setting of the Ordovician clastic deposits in the southern Puna basin, NW Argentina. Sedimentology 50: 1079-1104.

Manuscript received: December 18, 2018; revised/accepted: March 18, 2019; available online: September 30, 2019. 